\title{
Zastosowanie metody RHS \\ w badaniach stanu hydromorfologicznego rzeki górskiej powyżej i poniżej zbiornika retencyjnego (na przykładzie Ropy w Beskidzie Niskim)
}

\author{
Application of the RHS method in hydromorphological studies \\ of a mountain river above and below a storage reservoir \\ (as exemplified by the Ropa River in the Beskid Niski Mts.)
}

\begin{abstract}
MALGORZATA KIJOWSKA
Stacja Naukowo-Badawcza IGiPZ PAN, 38-311 Szymbark 430; gkijowska@interia.pl;

LUKASZ WIEJACZKA

Instytut Geografii i Przestrzennego Zagospodarowania im. S. Leszczyckiego PAN, 31-018 Kraków, ul. św. Jana 22; uhasz@poczta.onet.pl
\end{abstract}

\begin{abstract}
Zarys treści. W artykule przedstawiono wyniki oceny stanu hydromorfologicznego górskiej rzeki Ropy (Beskid Niski) z wykorzystaniem metody River Habitat Survey, dotychczas stosowanej głównie w obszarach nizinnych środkowej i północnej Polski. Do waloryzacji rzeki wybrano dwa odcinki Ropy: powyżej i poniżej zbiornika retencyjnego Klimkówka. Na podstawie wyników kartowania terenowego obliczono dwa podstawowe wskaźniki jakości siedliska: tzw. wskaźnik naturalności $(H Q A)$ oraz przekształcenia siedliska (HMS). Za ich pośrednictwem możliwa jest ocena hydromorfologiczna cieku zgodnie z wymaganiami Ramowej Dyrektywy Wodnej (RDW). Wskazano także na zalety i problemy wynikające z zastosowania metody RHS w zlewniach górskich, sugerując modyfikację wyboru kartowanych elementów i dostosowanie przedziałów klas wskaźników do warunków fizjograficznych Polski południowej.
\end{abstract}

Słowa kluczowe: metoda River Habitat Survey, stan hydromorfologiczny, rzeka Ropa, zbiornik Klimkówka, Beskid Niski.

\section{Uwagi wstępne}

Obowiązek monitorowania i oceny stanu hydromorfologicznego wód powierzchniowych wprowadza Dyrektywa 2000/60/WE Parlamentu Europejskiego i Rady z dnia 23 października 2000 r., ustanawiająca ramy wspólnotowego działania w dziedzinie polityki wodnej, czyli tzw. Ramowa Dyrektywa Wodna (RDW). Zgodnie z założeniami RDW stan ekologiczny wód wyznaczają elementy biologiczne, które zależą m.in. od czynników abiotycznych, obejmujących ele- 
menty hydromorfologiczne oraz fizykochemiczne. Najważniejszym celem środowiskowym RDW jest osiągnięcie do 2015 r. dobrego stanu wód powierzchniowych, poprzez realizację odpowiednio przygotowanych planów gospodarowania wodami w dorzeczach.

Ocena stanu hydromorfologicznego rzek jest jednym z wymagań służących realizacji procedur RDW, m.in. określeniu warunków referencyjnych rzeki, a także planowaniu działań stanowiących elementy zarządzania zlewnią, w tym związanych z ochroną przeciwpowodziową i renaturyzacją rzek. Stan hydromorfologiczny zależy od liczebności elementów naturalnych i antropogenicznych, a także ich wzajemnych proporcji - im większa przewaga elementów naturalnych, tym lepszy stan ekologiczny cieku. Dominacja składowych antropogenicznych świadczy natomiast o wyraźnym przekształceniu środowiska rzecznego przez człowieka.

Funkcjonowanie zbiorników retencyjnych ma istotny wpływ na kształtowanie się stanu hydromorfologicznego rzek, na odcinkach w zasięgu tego typu obiektów antropogenicznych. Przegrodzenie rzeki sztuczną przegrodą powoduje zakłócenie równowagi dynamicznej koryta, wskutek czego powstają dwa odmienne odcinki o zróżnicowanych warunkach. Istotność oceny hydromorfologicznej rzek z występującymi w ich biegu zbiornikami retencyjnymi wynika z potrzeby określenia rodzaju zmian, które zachodzą w środowisku rzeki po uruchomieniu zbiornika retencyjnego oraz ich dalszego monitorowania. Negatywny wpływ zbiorników retencyjnych na środowisko przyrodnicze jest w literaturze naukowej szeroko opisywany i dyskutowany (m.in. Achrem i Gierszewski, 2007; Szczerkowska-Majchrzak i Grzybkowska, 2008; Wiejaczka, 2009).

Głównym celem badań było określenie wpływu zbiornika retencyjnego Klimkówka na stan hydromorfologiczny Ropy oraz próba przetestowania brytyjskiej metody River Habitat Survey (RHS) w warunkach rzeki górskiej. W niniejszym artykule przedstawiono wyniki kartowania hydromorfologicznego rzeki Ropy, po 16 latach funkcjonowania zbiornika Klimkówka. Badania przeprowadzono na dwóch wybranych odcinkach rzeki, zlokalizowanych powyżej i poniżej zbiornika. Po uruchomieniu w 1994 r. zbiornika retencyjnego na Ropie, pierwotne środowisko przyrodnicze doliny oraz koryta rzeki zostało w istotny sposób przekształcone (Wiejaczka, 2009). Do tej pory nie prowadzono jednak badań nad stanem hydromorfologicznym rzeki.

W Polsce aplikacja metody RHS prowadzona była przede wszystkim w ramach projektu europejskiego STAR (Standarisation of River Classifications), mającego na celu ujednolicenie procedur badawczych (Gręplowska i Żołnacz, 2006; Jusik i Szoszkiewicz, 2009). Większość polskich opracowań, w których wykorzystano omawianą metodę dotyczy jednak rzek nizinnych środkowej i północnej części Polski (m.in. Szoszkiewicz i inni, 2004; Wasilewicz i Oglęcki, 2006; Czerniawska-Kusza i Szoszkiewicz, 2007; Raven i inni, 2008; Jusik i Szoszkiewicz, 2009; Szoszkiewicz i inni, 2009 a, b; 2010). W odniesieniu do rzek górskich tego typu 
prace są rzadkością (Gręplowska i Żołnacz, 2006). Warto również zaznaczyć, że w przypadku rzek karpackich, w badaniach hydromorfologicznych koryt powszechnie wykorzystywany jest system opracowany na Uniwersytecie Jagiellońskim (Kamykowska i inni, 1999), który opiera się na wskaźnikach geomorfologicznych i hydrologicznych, jednak nie umożliwia sklasyfikowania danego odcinka cieku pod kątem jakości ekologicznej (Gręplowska i Żołnacz, 2006).

\section{Metody oceny hydromorfologicznej rzek}

Istnieje wiele metod stosowanych w Polsce i w Europie do oceny hydromorfologii rzek. W Europie zachodniej już w latach 1980. i 1990., w wyniku wzrostu świadomości ekologicznej, zostały opracowane i wdrożone liczne metody, dzięki którym można było określać stan hydromorfologiczny cieków (Ilnicki i Lewandowski, 2008). Pierwsze oceny wykonane zostały w Niemczech, Holandii, Austrii i Szwajcarii, gdzie opierano się na różnicach między stanem aktualnym rzeki a uznanym za nieprzekształcony (Adynkiewicz-Piragas, 2006).

Poniżej przedstawiono tylko wybrane metody do oceny stanu hydromorfologicznego rzek używane w Europie i w Polsce. Wśród metod stosowanych w Niemczech często podaje się opracowaną w 2002 r. przez Zespół Roboczy Krajów Związkowych ds. Wody RFN (LAWA) metodę przeglądową, różnicującą sposób wykonywania oceny hydromorfologicznej cieków małych, średnich i dużych oraz ograniczającą zakres prac terenowych. W Austrii w 2005 r. powstała metoda "Screening", która nie wymaga wykonywania prac terenowych, a zaleca wykorzystywanie zdjęć lotniczych (Adynkiewicz-Piragas, 2006). W Danii opracowano metodę indeksową (DSHI) (2003 r.), która może być wykorzystywana w odniesieniu do małych rzek nizinnych, natomiast we Francji metodę SEQ Physique (1998 r.) dotyczącą głównie oceny i obserwacji stanu hydromorfologicznego w porównaniu ze stanem referencyjnym różnych typów rzek (Adynkiewicz-Piragas, 2006). W 2003 r. ukazały się wytyczne do oceny stanu hydromorfologicznego rzek opracowane przez Europejski Komitet Normalizacyjny (CEN, EN 14 614), które stanowią połączenie metod niemieckich, francuskich i brytyjskich. Głównym założeniem jest badanie jednolitych części wód (JCW). W tej metodzie można analizować tylko wybrane odcinki, ale powinny one wykazywać istotne różnice cieku (Ilnicki i Lewandowski, 2008).

W Polsce badania hydromorfologiczne waloryzacji rzek przeprowadzono po raz pierwszy w 1992 r. w Katedrze Ochrony i Kształtowania Środowiska Akademii Rolniczej (KOKŚ) w Poznaniu. Zostały one opublikowane w 1995 r. (Ilnicki, 1995) i odpowiadają normie europejskiej EN 14 614. W opracowanej później metodzie FotMoR odnoszącej się do oceny stanu rzek nizinnych istotną rolę odgrywały nie tylko badania terenowe, ale także wykorzystanie zdjęć lotniczych i obrazów satelitarnych (Lewandowski i inni, 2006). W nowej metodzie MHR (Monitoring Hydromorfologiczny Rzek), opracowanej w 2009 r. na potrzeby 
GIOŚ (Głównego Inspektoratu Ochrony Środowiska), określa się współczynniki jakości ekologicznej (WJE), które umożliwiają ocenę stanu i potencjału ekologicznego jednolitych części wód powierzchniowych (Ilnicki i inni, 2011). Metoda umożliwia wszechstronną ocenę złożonych ekosystemów rzeki i jej doliny oraz odpowiada wymogom międzynarodowych aktów prawnych.

\section{Metoda River Habitat Survey}

Metoda River Habitat Survey (RHS) została opracowana na początku lat 1990. przez brytyjską Agencję Środowiska (Environmental Agency) i jest zgodna z wymaganiami Europejskiego Komitetu Normalizacyjnego CEN (Comiteé Européen de Narmalisation) odnoszącymi się do Ramowej Dyrektywy Wodnej. Jest najbardziej rozpowszechnioną metodą nie tylko w Wielkiej Brytanii, ale również w Niemczech, Szwecji, Danii, Czechach i Łotwie, a w zmodyfikowanej wersji we Włoszech, Grecji i Portugalii (Hawley i inni, 2002; Buffagni i inni, 2004). W Polsce stosuje się ją od końca lat 1990., a jej polska wersja została opracowana w 2007 r. (Szoszkiewicz i inni, 2007) i opublikowana w formie podręcznika terenowego, nieznacznie zmienianego w kolejnych latach. System RHS w ostatnich latach zyskał dużą popularność, pozwala bowiem na szczegółowy opis warunków hydromorfologicznych dla wybranego 500-metrowego odcinka reprezentatywnego. Zgodnie z założeniami systemu RHS wybór profilu do analizy powinien być losowy (Raven i inni, 2000). Badania przeprowadza się dwuetapowo. W pierwszym etapie dokonuje się charakterystyki podstawowych cech morfologicznych koryta i brzegów w 10 profilach kontrolnych, rozmieszczonych co $50 \mathrm{~m}$ (dodatkowo wyznacza się 11 profil, który uwzględniony jest podczas pomiarów współrzędnych geograficznych podobnie jak profile 1 i 6). Ocenia się także strukturę roślinności wodnej i brzegowej oraz użytkowanie terenu doliny rzecznej. Drugi etap obejmuje opis syntetyczny całego odcinka badawczego, w którym uwzględnia się różne formy morfologiczne i przekształcenia, niezarejestrowane $\mathrm{w}$ poprzednim etapie. Badania realizowane według metody RHS pozwalają na zebranie około 400 parametrów charakteryzujących stan hydromorfologiczny danego odcinka rzeki. Pozyskany materiał pozwala obliczyć syntetyczne wskaźniki (HQA, HMS), będące wypadkową wielu pojedynczych parametrów podstawowych, które umożliwiają z kolei ocenę właściwości hydromorfologicznych rzeki w formie liczbowej. Dzięki wskaźnikowi naturalności HQA (Habitat Quality Assessment) możliwa jest ocena różnorodności naturalnych elementów koryta i doliny. Składnikami oceny są: parametry fizyczne koryta, cechy brzegów, typy roślinności korytowej, struktura roślinności na skarpach, zadrzewienia i użytkowanie terenu w odległości $50 \mathrm{~m}$ od brzegu. Wskaźnik przekształcenia siedliska HMS (Habitat Modification Score) oblicza się na podstawie informacji o rodzaju i liczbie budowli wodnych, umocnieniach brzegów, zmianach profilu koryta, zaburzeniach w stosunkach wodnych doliny. 
Elementom tym przepisuje się punkty, których suma pozwala na zakwalifikowanie badanego odcinka cieku do określonej kategorii (tab. 1). Ciek ma najlepsze warunki hydromorfologiczne w przypadku wysokich wartości wskaźnika HQA i niskich - HMS.

Tabela 1. Kategoria cieków ze względu na modyfikację (HMS) i naturalność siedliska (HQA) Category of watercourse in regard to modification (HMS) and naturalness of habitat (HQA)

\begin{tabular}{|c|l|c|l|}
\hline $\begin{array}{c}\text { Wartość HMS } \\
\text { HMS value }\end{array}$ & $\begin{array}{c}\text { Rodzaj siedliska } \\
\text { Type of habitat }\end{array}$ & $\begin{array}{c}\text { Wartość HQA } \\
\text { HQA value } \\
(\%)\end{array}$ & $\begin{array}{c}\text { Jakość siedliska } \\
\text { Quality of habitat }\end{array}$ \\
\hline $0-2$ & $\begin{array}{l}\text { prawie naturalne } \\
\text { almost natural } \\
\text { nieznacznie zmienione } \\
\text { slightly changed }\end{array}$ & $80-100$ & $\begin{array}{l}\text { bardzo wysoka } \\
\text { very high } \\
\text { mało zmienione } \\
\text { little changed } \\
\text { wysoka } \\
\text { high }\end{array}$ \\
$21-44$ & $\begin{array}{l}\text { znacznie zmienione } \\
\text { much changed } \\
\text { bardzo zmienione } \\
\text { highly changed }\end{array}$ & $20-40$ & $\begin{array}{l}\text { dostateczna } \\
\text { nufficient } \\
\text { lowa }\end{array}$ \\
\hline
\end{tabular}

Źródło: Walker i inni (2002).

Source: Walker et al. (2002).

Terminologia stosowana w metodzie RHS, przetłumaczona z języka angielskiego, utrudnia interpretację oraz aplikację metody. Stanowi ona często daleko idące uproszczenie terminów używanych w różnych dziedzinach nauk przyrodniczych i technicznych. Na brak jednolitości i zrozumiałości terminologii wykorzystywanych $\mathrm{w}$ metodach oceny hydromorfologicznej cieków zwraca uwagę P. Ilnicki (2006). Dobrym przykładem może być określenie 'ziemia' odnoszące się w metodzie RHS do luźnego, drobnoziarnistego, próchniczego materiału budującego brzegi koryta, które w gleboznawstwie nie występuje. Również podział luźnych frakcji skalnych na 'kamyki' (16-64 mm) i 'kamienie' (64-256 mm) budzi terminologiczne zastrzeżenia. Dla osoby nieznającej metody RHS, niezrozumiały może być także termin 'szczyt brzegu', definiowany jako teren przyległy do krawędzi brzegu, przechodzący w terasę zalewową. Podobnych przykładów niejasności terminologicznych w metodzie RHS jest znacznie więcej. Może to utrudniać przekaz informacji autorom opracowań, w których zastosowano odniesienia do RHS, a także interpretację publikowanych wyników osobom niezaznajomionym z tą metodą. Założeniem RHS jest 
jednak łatwość w jej adaptacji i stosowaniu. Jest opracowana w taki sposób, aby mogła być wykorzystywana przez specjalistów z różnych dziedzin nauki, dlatego zastosowanie uproszczonych terminów naukowych lub popularnych określeń dotyczących różnych elementów środowiska przyrodniczego było nieuniknione i uzasadnione. J. Suchożebrski (2010) zaznacza, że ograniczeniem stosowania metody RHS jest prowadzenie badania wyłącznie w okresie wegetacyjnym; istnieje również możliwość popełnienia błędów przez niedoświadczonych badaczy w czasie kartowania terenowego. Ważne jest, aby osoba stosująca metodę znała dokładnie interpretację zapisów w formularzach i miała doświadczenie, dzięki któremu uzyska powtarzalne wyniki oceny tego samego odcinka cieku. Wśród najczęstszych błędów wymienia się nieprawidłowe określenie rodzaju dominującego materiału dna i brzegów koryta oraz typów roślinności w korycie, co wpływa z kolei na nieprawidłowe wartości wskaźników HQA i HMS, a tym samym na złą ocenę stanu hydromorfologicznego cieku (Szoszkiewicz i inni, 2005; Suchożeberski, 2010). Duże znaczenie (a zarazem trudność) dla poprawności oceny hydromorfologicznej metodą RHS ma dobór odcinka reprezentatywnego dla całej rzeki, w którym wykonuje się kartowanie. Ze względu na zmienność cech hydromorfologicznych wzdłuż biegu rzeki (szczególnie rzeki górskiej), wybrany nawet $\mathrm{w}$ drodze wnikliwej analizy odcinek badawczy może nie oddawać stanu hydromorfologicznego całej rzeki. Szczegółowe wytyczne dotyczące prowadzenia badań oceny hydromorfologicznej metodą RHS, opis wymienionych powyżej wskaźników HQA i HMS, jak również wyjaśnienie stosowanej w niniejszym opracowaniu terminologii zawiera praca K. Szoszkiewicza i innych (2009b). Aby uniknąć niejasności, w publikacjach wykorzystujących terminologię metody RHS powinno znaleźć się wyjaśnienie zastosowanych terminów mogących budzić wątpliwości czytelników oraz/lub odwołanie do wyżej cytowanego opracowania (lub jego uaktualnionych wersji), stanowiącego podstawową lekturę dla wszystkich zainteresowanych metodą. Można również używać obowiązującej terminologii, m.in. geomorfologicznej i hydrologicznej w opisie, co nie wpłynie w żadnym stopniu na końcową ocenę waloryzacji koryta. Niewątpliwym walorem metody RHS jest jej przystępność, kompleksowość opisu cieku wraz z doliną rzeczną (na odległość 50 metrów od koryta), a także ocena hydromorfologiczna tylko wybranych odcinków badawczych wzdłuż cieku - dzięki temu można uniknąć problemów ekonomicznych i logistycznych napotkanych podczas oceny całego cieku (Suchożebrski, 2010).

\section{Charakterystyka obszaru badań}

Za reprezentatywny odcinek rzeki Ropy powyżej zbiornika Klimkówka uznano fragment zlokalizowany kilkadziesiąt metrów powyżej ujścia Zdyni do Ropy, odcinek badawczy poniżej zbiornika wybrano zaś około $100 \mathrm{~m}$ poniżej zapory wodnej (ryc. 1). Wymienione odcinki rzeki oddzielone od siebie zbiornikiem 
retencyjnym, różnią się istotnie rodzajem i intensywnością procesów korytowych, jak również wielkością przepływu. Zbiornik Klimkówka stanowi barierę w transporcie fluwialnym rzeki. Woda wypływająca ze zbiornika jest pozbawiona materiału klastycznego, a posiadaną energię zużywa nie na transport materiału, lecz na erozję dna i brzegów koryta. Badania z wykorzystaniem metody RHS przeprowadzono 18 września 2010 r. W tym dniu przepływ Ropy na odcinku powyżej zbiornika Klimkówka wynosił około $1 \mathrm{~m}^{3} \cdot \mathrm{s}^{-1}$, natomiast poniżej zapory $4 \mathrm{~m}^{3} \cdot \mathrm{s}^{-1}$. Warunki hydrometeorologiczne w trakcie badań odpowiadały wymaganiom stawianym metodzie RHS.

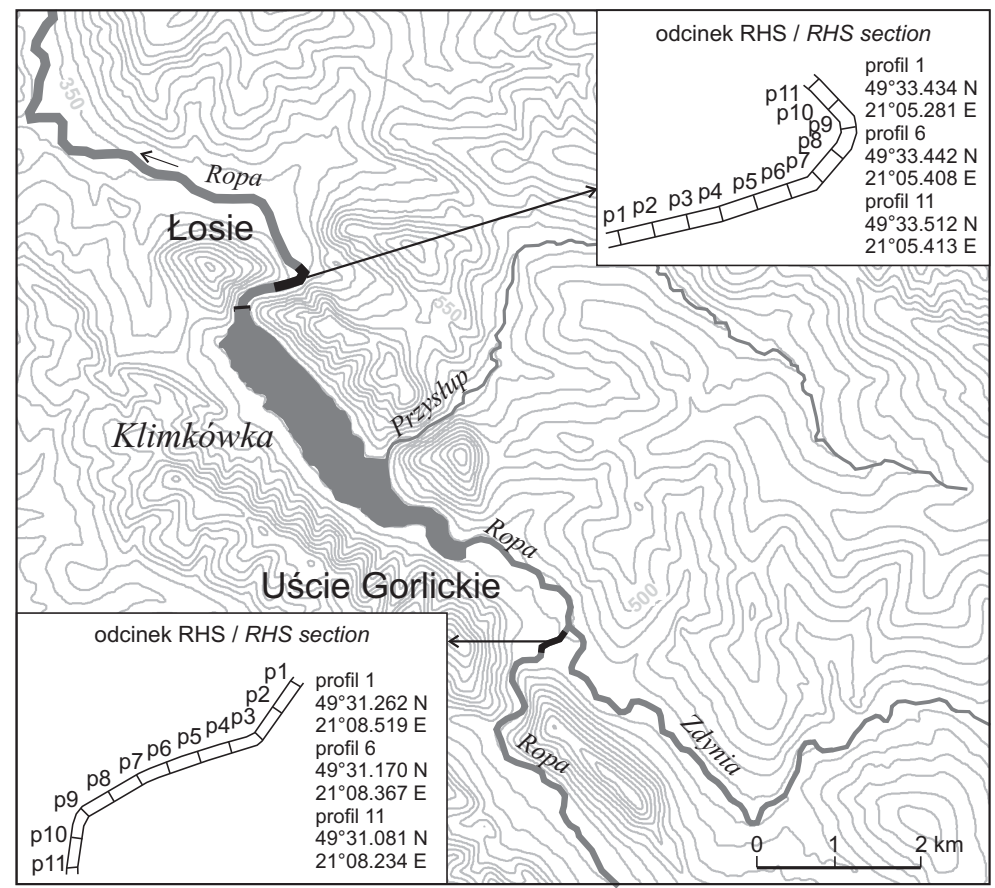

Ryc. 1. Lokalizacja odcinków badawczych oraz poszczególnych profili kontrolnych Location of the research sections, and of each control profile

\section{Syntetyczna ocena stanu hydromorfologicznego Ropy powyżej i poniżej zbiornika retencyjnego Klimkówka}

Stan hydromorfologiczny odcinków Ropy powyżej i poniżej zbiornika retencyjnego Klimkówka przedstawia tabela 2. Zastosowano w niej terminologię używaną w formularzu i instrukcji metody RHS (Szoszkiewicz i inni, 2007), jednak niektóre terminy zastąpiono fachowym nazewnictwem hydrologicznym i geo- 
morfologicznym w celu uniknięcia niejasności. Jak zaznaczono wcześniej, nie ma to wpływu na poprawność oceny stanu hydromorfologicznego rzeki.

Podstawowym elementem różniącym porównywane odcinki rzeki Ropy jest kształt samej doliny, która powyżej zbiornika jest płaskodenna z wyraźnie wykształconymi terasami, zaś poniżej - przełomowa (ryc. 2).

Omawiając różnice spowodowane oddziaływaniem zbiornika Klimkówka należy zaznaczyć, że materiał wyścielający dno koryta powyżej zbiornika, to przede wszystkim żwir i kamyki (fot. 1), transportowane z większych odległo-
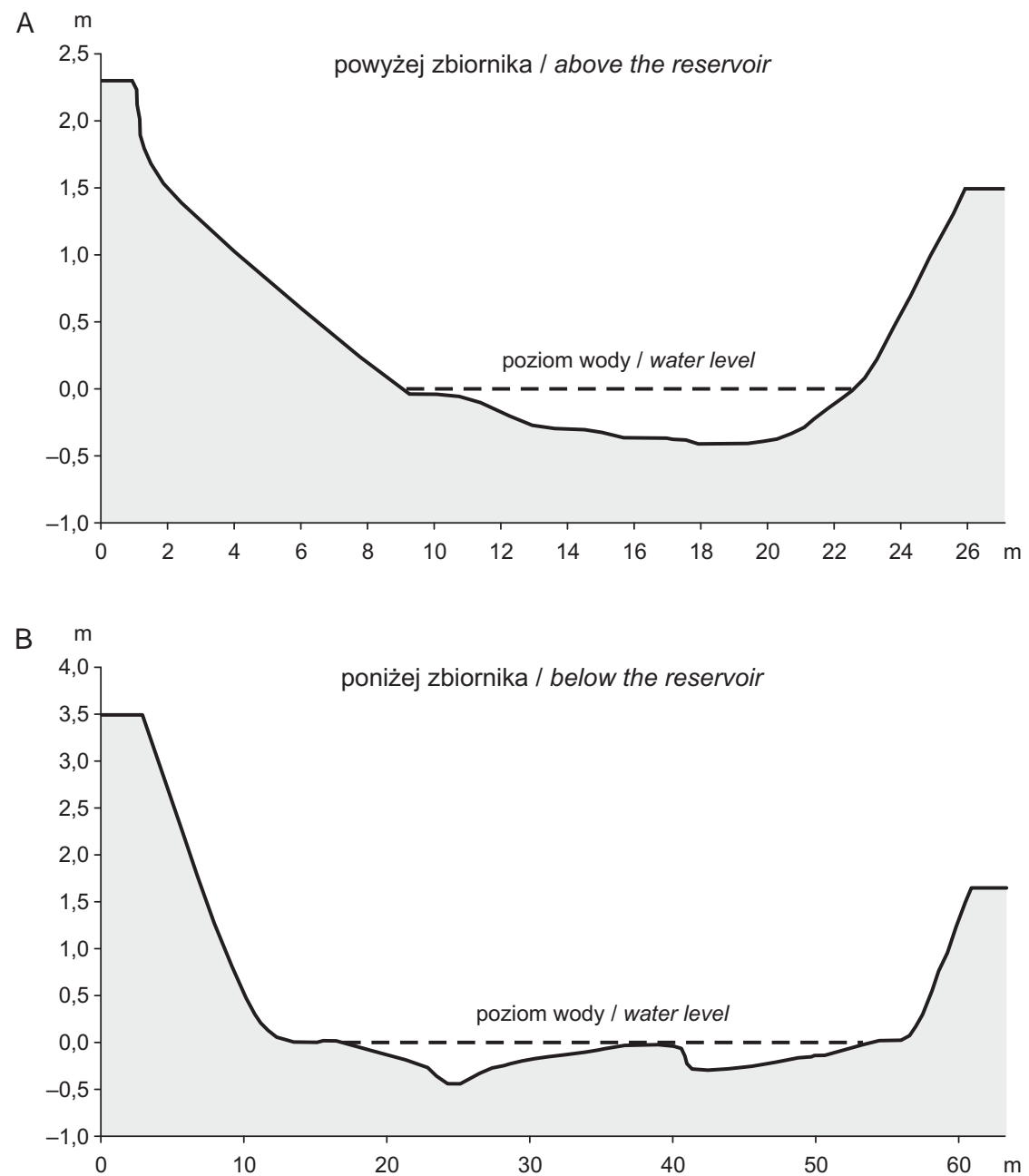

Ryc. 2. Przykładowe profile koryta Ropy na odcinkach badawczych powyżej i poniżej zbiornika Klimkówka

Example profile of the Ropa in the section above the Klimkówka Reservoir 
ści w czasie wezbrań. Zbiornik powstrzymuje ich dalsze przemieszczanie się w dół rzeki. Poniżej zapory frakcja materiału jest natomiast wyraźnie większa, ponieważ wyerodowany materiał nie został jeszcze przetransportowany dalej (fot. 2). Ponadto na odcinku poniżej zbiornika łatwo zauważalnymi naturalnymi elementami dna koryta są wystające głazy, które powyżej zbiornika występują sporadycznie.

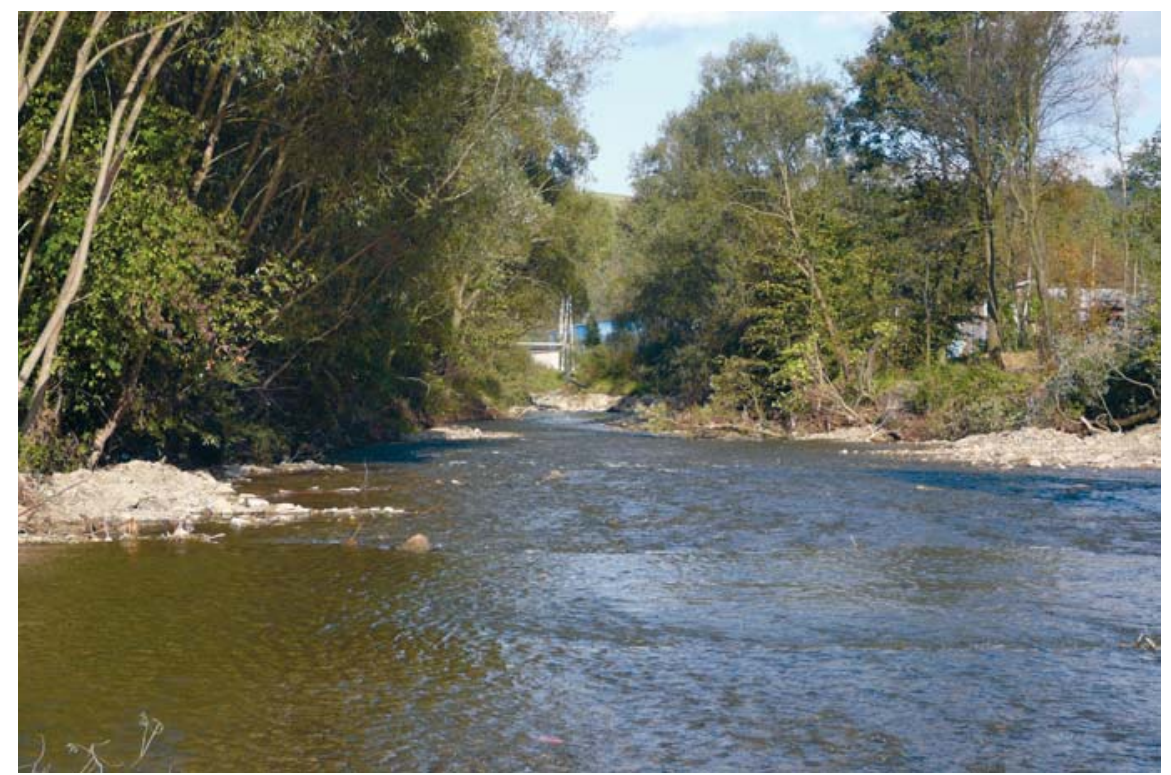

Fot. 1. Koryto Ropy na odcinku badawczym powyżej zbiornika Klimkówka The channel of the Ropa in the research section above the Klimkówka Reservoir (fot./photo: M. Kijowska)

Budowle wodne odnotowane w czasie badań terenowych na odcinku powyżej zapory - to most średni (według metody RHS most z umocnieniami wzdłuż brzegu o długości 10-25 m) z przyczółkami betonowymi oraz most mały (umocnienia brzegowe $>10 \mathrm{~m}$ ) - pozostałość po drewnianej kładce zniszczonej w czasie wezbrania w czerwcu 2010 r. Poniżej małego mostu zlokalizowana jest przeprawa przez rzekę, bez sztucznych umocnień brzegów i koryta, niewpływająca na spiętrzenie wody. Poniżej zbiornika zarejestrowano most średni z dwiema podporami śródkorytowymi oraz dużą przeprawę przez rzekę z umocnieniami brzegów i koryta w postaci płyt betonowych.

Na odcinku poniżej zbiornika Klimkówka zaobserwowano na wynurzonych głazach powszechnie występujące mchy i wątrobowce, co jest efektem ustabilizowania stanu wody na jednakowym poziomie przez większą część roku. 
W korycie powyżej zbiornika nie stwierdzono żadnej roślinności wodnej, m.in. z powodu krótkich okresów niżówkowych niesprzyjających rozwojowi roślinności w korycie (częste wahania stanu wody). W dnie koryta Ropy powyżej zbiornika Klimkówka zaznaczają się ślady modyfikacji antropogenicznej w postaci wyrównanych łach żwirowo-kamienistych, powstałych po wezbraniu w czerwcu 2010 r. (fot. 3).

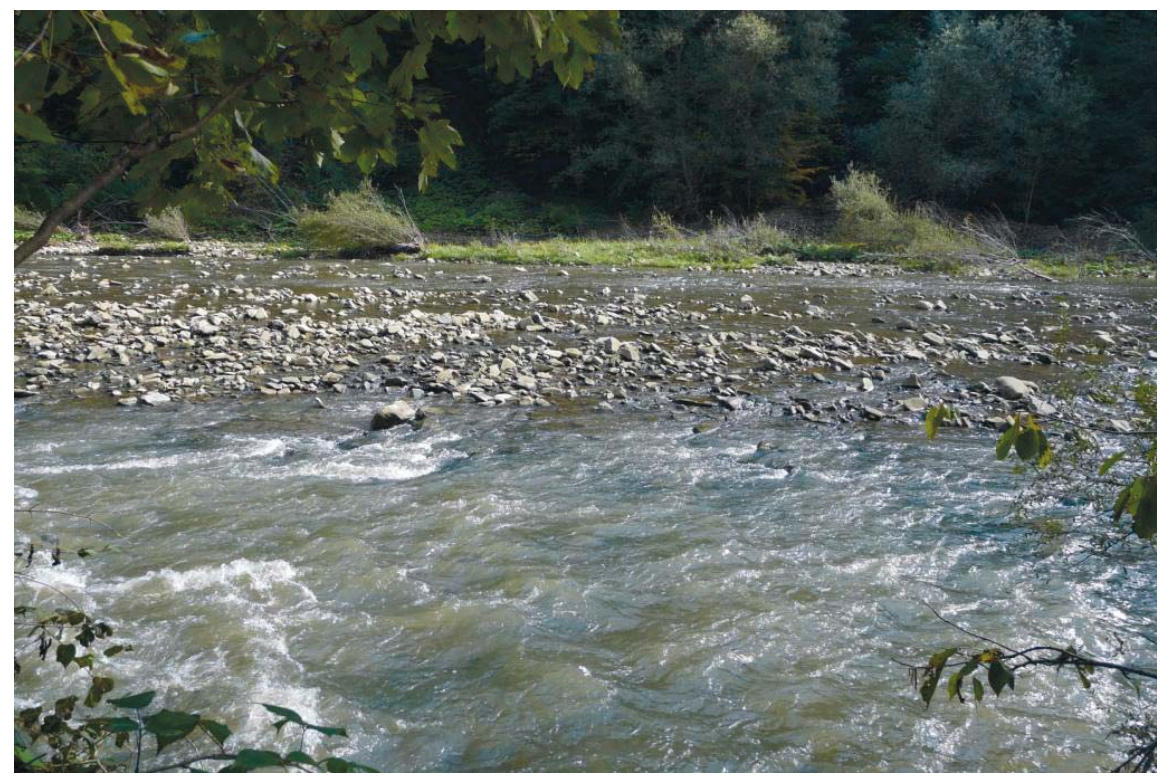

Fot. 2. Koryto Ropy na odcinku badawczym poniżej zbiornika Klimkówka The channel of the Ropa in the research section below the Klimkówka Reservoir (fot./photo: M. Kijowska)

Przepływ na odcinku powyżej zbiornika można zdefiniować jako wartki (na powierzchni wody tworzą się „zmarszczki” o wysokości około $1 \mathrm{~cm}$, przemieszczające się w dół rzeki) oraz rwący (według metody RHS burzliwy przepływ z krótkimi falami o szklistych grzbietach), natomiast poniżej zapory wodnej przepływ w większości profili sklasyfikowano jako gładki (powolny przepływ laminarny, niewzburzający powierzchni wody), bądź wartki. Poniżej mostu wyróżniono także przepływ rwący oraz chaotyczny (połączenie kilku typów przepływu). Poniżej zbiornika stwierdzono występowanie trzech bystrz, jednego plosa oraz jednego odsypu meandrowego, nieutrwalonego roślinnością (fot. 4), natomiast powyżej odnotowano jedno bystrze.

Brzegi koryta powyżej i poniżej zbiornika buduje głównie materiał gliniastogruzowy, a powyżej zbiornika także narzut kamienny będący ich umocnieniem 
(tab. 2). Na porównywanych odcinkach dominuje brzeg pionowy podmyty lub z podstawą, utworzony z osuniętego materiału brzegowego oraz brzeg stromy. Dno koryta poniżej zbiornika retencyjnego jest zdecydowanie bardziej niewyrównane aniżeli powyżej, co jest efektem wzmożonej erozji zachodzącej na skutek funkcjonowania zbiornika.

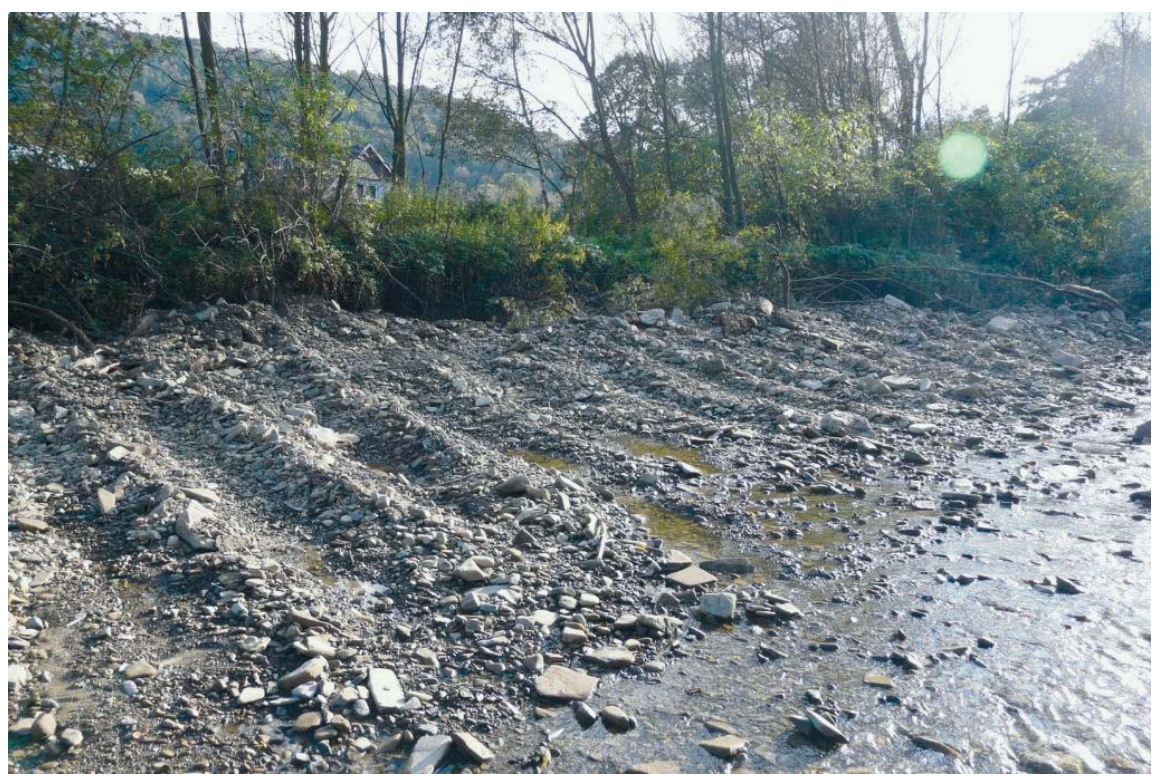

Fot. 3. Modyfikacja dna koryta Ropy na odcinku badawczym powyżej zbiornika Klimkówka Modification of the bottom of the Ropa channel in the research section above the Klimkówka Reservoir (fot./photo: E. Wiejaczka)

Antropogeniczne elementy można zauważyć także w dnie doliny Ropy, w bezpośrednim sąsiedztwie koryta rzeki. Obok naturalnych form użytkowania terenu takich jak zakrzaczenia, wysokie ziołorośla czy las liściasty i/lub mieszany, dużą powierzchnię zajmuje zabudowa podmiejska (drogi asfaltowe) oraz użytki rolne w postaci intensywnie użytkowanych łąk czy gruntów ornych. Na podstawie badań terenowych można stwierdzić, że udział elementów antropogenicznych w użytkowaniu terenu na obydwu analizowanych odcinkach jest porównywalny i wynosi około 50\%. Struktura roślinności brzegowej na badanych odcinkach jest w dużej mierze analogiczna - dominuje struktura prosta (dwa lub trzy typy wegetacji) nad jednolitą (jeden typ roślinności, brak krzewów i drzew), ale częsty jest także brak pokrycia roślinnego.

Koryto Ropy powyżej zbiornika jest zatem paradoksalnie bardziej zmodyfikowane przez człowieka niż odcinek poniżej zapory, gdzie teoretycznie wpływ 
antropogeniczny powinien być znacznie większy. Wynika to z obecności na odcinku powyżej zbiornika umocnień brzegowych służących stabilizacji brzegów oraz efektów prac mających na celu udrożnienie koryta rzeki. Spostrzeżenie to potwierdza wielkość wskaźnika HMS, która dla odcinka powyżej zbiornika wyniosła 18, natomiast dla odcinka poniżej zapory 11 (oba odcinki wykazują generalnie małe przekształcenie warunków hydromorfologicznych cieków - tab. 1). Wartości wskaźnika HQA (50 powyżej i 56 poniżej zbiornika) świadczą o dostatecznej naturalności hydromorfologicznej Ropy (tab. 1). Odcinek poniżej zapory odznacza się jednak relatywnie większą liczbą i zróżnicowaniem naturalnych elementów morfologicznych w obrębie koryta i otoczenia cieku.

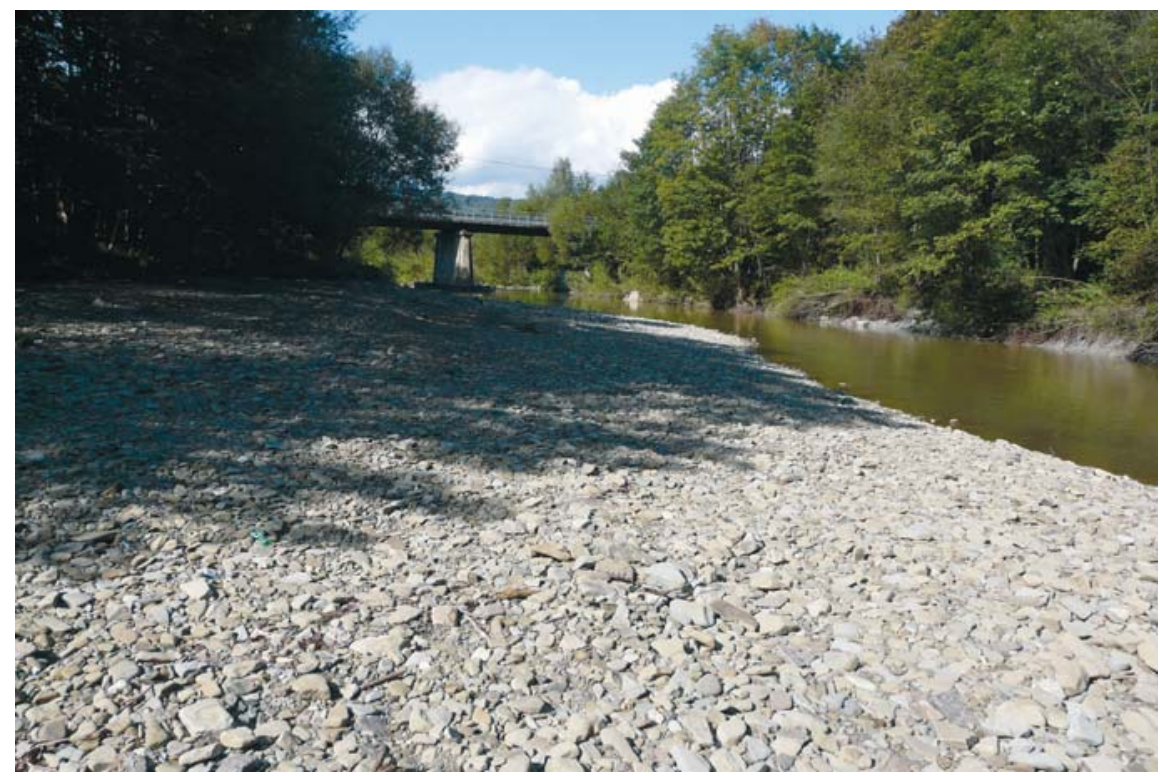

Fot. 4. Odsyp meandrowy nieutrwalony roślinnością, ploso oraz duży most w korycie Ropy na odcinku badawczym poniżej zbiornika Klimkówka

Non-vegetated meander bar, river pool and large bridge below the Klimkówka Reservoir (fot./photo: E. Wiejaczka)

\section{Podsumowanie}

Badania prowadzone w dolinie Ropy wykazały, że brytyjska metoda River Habitat Survey, zgodna z wymaganiami RDW, służąca do oceny, charakterystyki i klasyfikacji rzek pod względem warunków hydromorfologicznych, może być stosowana również w obszarach górskich i podgórskich, lecz po wprowadzeniu zmian $\mathrm{w}$ oryginalnym formularzu systemu m.in. na podstawie eksperymentów 
terenowych. Należy przede wszystkim właściwie dobierać elementy hydromorfologiczne, które podlegają kartowaniu. Zmiany wskaźników (zwłaszcza HQA) mogą jednak wpłynąć na sposób dokonywania oceny. O zmianach tych pisali już Z. Gręplowska i J. Żołnacz (2006) przy ocenie hydromorfologicznej zlewni Stradomki (prawobrzeżny dopływ Raby), wskazując, że kontrowersyjna jest kwestia roślinności w korytach górskich i podgórskich, gdyż jej brak w ciekach Polski południowej wcale nie świadczy o niepokojącym stanie rzek.

Metoda RHS wymaga również ujednolicenia i sprecyzowania stosowanych terminów, gdyż mogą one być niezrozumiałe dla czytelnika i odbiegają od terminologii stosowanej w różnych dziedzinach nauk przyrodniczych i technicznych. Istotna jest także weryfikacja przedziałów klas wskaźników i dostosowanie ich do warunków referencyjnych, których określenie w Polsce południowej jest bardzo trudne i wymaga wieloletnich badań i zgromadzenia dość bogatej bazy danych wyników pomiarów terenowych. Specyficzny charakter rzek górskich i podgórskich tzn. duża zmienność na stosunkowo niewielkich odcinkach cieku sprawia, że podczas kartowania ważny jest również dobór profili objętych oceną hydromorfologiczną. Potwierdzeniem tego są różne warunki morfologiczne odnotowane w korycie Ropy powyżej i poniżej zbiornika Klimkówka.

Zbiornik Klimkówka wpływa na stan hydromorfologiczny rzeki poniżej jego lokalizacji, poprzez zmianę reżimu hydrologicznego rzeki oraz przebieg procesów fluwialnych, mających wpływ na morfologię koryta. Waloryzacja hydromorfologiczna Ropy z wykorzystaniem metody RHS wykazała, że funkcjonowanie zbiornika nie powoduje jednak istotnych przekształceń decydujących o pogorszeniu warunków hydromorfologicznych w odniesieniu do warunków niezakłóconych działalnością zbiornika, obserwowanych powyżej jego lokalizacji. Wyższą wartość wskaźnika HMS powyżej zbiornika należy wiązać głównie z przeprowadzoną regulacją rzeki, mającą na celu ochronę brzegów przed erozją oraz zapewnienie drożności koryta.

Przedstawiona w niniejszym artykule analiza nie wyczerpuje tematu wpływu zbiorników wodnych na warunki hydromorfologiczne rzek oraz dostosowania metody RHS do warunków rzeki górskiej, stanowi jednakże punkt wyjścia do dalszych badań.

\section{Piśmiennictwo}

Achrem E., Gierszewski P., 2007, Zbiornik Włocławski, Inspekcja Ochrony Środowiska, Biblioteka Monitoringu Środowiska, Bydgoszcz.

Adynkiewicz-Piragas M., 2006, Hydromorfologiczna ocena cieków wodnych w krajach Unii Europejskiej jako element wspierający ocenę ekologicznego stanu rzek zgodnie z wymogami ramowej dyrektywy wodnej, Infrastruktura i Ekologia Terenów Wiejskich, $4,3$.

Buffagni A., Erba S., Armanini. D., De Martini D., Somare S., 2004, Aspetti idromorfologici e carattere Lentico-lotico dei fiumi mediterranei: River Habitat Survey e descrit- 
tore LRD. Classificazione ecologica e carattere lentico-lotico in fiumi mediterranei, Quaderni Istituto Ricerca Acque, Roma, 122, s. 41-63.

CEN, 2003, Water quality - Guidance standard for assessing the hydromorphological features of rivers, EN-14614.

Czerniawska-Kusza I., Szoszkiewicz K., 2007, Biologiczna i hydromorfologiczna ocena wód płynacych na przyktadzie rzeki Mała Panew, Katedra Ochrony Powierzchni Ziemi, Uniwersytet Opolski, Opole.

Dyrektywa 2000/60/WE Parlamentu Europejskiego i Rady z dnia 23 października 2000 r. ustanawiająca ramy wspólnotowego działania w dziedzinie polityki wodnej.

Hawley D., Raven P. J., Anstey K. L., Crisp S., Freeman D., Cullis J., 2002, Riverside Explorer: an educational application of River Habitat Survey information, Aquatic Conservation, Marine and Freshwater Ecosystems, 12, 4, s. 457-469.

Gręplowska Z., Żołnacz J., 2006, Wstępna ocena metod waloryzacji morfologicznej rzek na przyktadzie zlewni Raby, Infrastruktura i Ekologia Terenów Wiejskich, 4, 3, Komisja Technicznej Infrastruktury Wsi, PAN, Oddział w Krakowie, s. 37-44.

Ilnicki P., 1995, Ekomorfologiczna waloryzacja cieków wodnych, Wiadomości Melioracyjne i Łąkarskie, 38, 1, s. 5-7.

Ilnicki P., 2006, Terminologia stosowana w badaniach hydromorfologicznych rzek, Gospodarka Wodna, 3, s. 94-98.

Ilnicki P., Lewandowski P., 2008, Metody hydromorfologicznej oceny rzek stosowane w Europie przed i po ustanowieniu Ramowej Dyrektywy Wodnej, Gospodarka Wodna, 10, s. 393-397.

Ilnicki P., Górecki K., Grzybkowski M., Krzemińska A., Lewandowski P., Sojka M., 2011, Badania hydromorfologii cieków nizinnych za pomoca metody MHR, Woda-Środowisko-Obszary Wiejskie, 11, s. 97-112.

Jusik Sz., Szoszkiewicz K., 2009, Zastosowanie systemu River Habitat Survey (RHS) w ocenie warunków hydromorfologicznych wód ptynacych w Polsce, Wiadomości Melioracyjne i Łąkarskie, 3, s. 106-110.

Kamykowska M., Kaszowski L., Krzemień K., 1999, River channel mapping instruction. Key to the river bed description, [w:] K. Krzemien (red.), River Channels - Pattern, Structure and Dynamics, Institute of Geography of the Jagiellonian University, Cracow, 104.

Lewandowski P., Olejnik M., Górecki K., 2006, Ekomorfologiczna waloryzacja Kanatu Mosińskiego metoda terenowa, Infrastruktura i Ekologia Terenów Wiejskich, 4, 3.

Raven P.J., Holmes N.T.H., Naura M., Dawson F.H., 2000, Using river habitat survey for environmental assessment and catchment planning in the UK, Hydrobiologia, 422, Springer, s. 359-367.

Raven P.J., Holmes N.T.H., Scarlett P., Szoszkiewicz K., Ławniczak A., Dawson F.H, 2008, River habitat and macrophyte surveys in Poland. Results from 2003 and 2007, Environment Agency, 29.

Suchożebrski J., 2010, Ocena hydromorfologiczna rzek metoda RHS - problemy praktyczne, [w:] A. Magnuszewski (red.), Hydrologia w ochronie i ksztattowaniu środowiska, Monografie, Komitet Inżynierii Środowiska PAN, 69, s. 333-340.

Szczerkowska-Majchrzak E., Grzybkowska M., 2008, Piętrzenia rzek i energia wodna: za i przeciw, Kosmos, Problemy Nauk Biologicznych, 57, 3-4, s. 295-303.

Szoszkiewicz K., Leśny J., Staniszewski R., Mendyk D., 2004, Zróżnicowanie parametrów ekomorfologicznych w ocenie rzek niżowych metoda River Habitat Survey (RHS), Przegląd Naukowy, Inżynieria i Kształtowanie Środowiska, 30, s. 67-76. 
Szoszkiewicz K., Staniszewski R., Zbierska J., Jusik S., Zgoła T., 2005, Możliwości wykorzystania systemu River Habitat Survey w ocenie hydromorfologicznej rzek na potrzeby Ramowej Dyrektywy Wodnej, [w:] Ecostatus. I Ogólnopolska Konferencja Naukowa „Wdrażanie Ramowej Dyrektywy Wodnej. Ocena stanu ekologicznego wód w Polsce”, Łódź, 07-09.12.2005, Uniwersytet Łódzki, Główny Inspektorat Ochrony Środowiska, Polskie Towarzystwo Hydrobiologiczne, Łódź, s. 42-43.

Szoszkiewicz K., Zgoła T., Jusik Sz., Hryc-Jusik B., Raven P., Dawson F.H., 2007, Ocena hydromorfologiczna wód ptynacych (River Habitat Survey), Bogucki Wydawnictwo Naukowe, Poznań.

Szoszkiewicz K., Zgoła T., Giełczewski M., Stelmaszczyk M., 2009a, Zastosowanie metody River Habitat Survey do waloryzacji hydromorfologicznej i oceny skutków planowanych dziatan renaturyzacyjnych, Nauka Przyroda Technologie, 3, 3.

Szoszkiewicz K., Zgoła T., Jusik S., Hryc-Jusik B., Dawson F.H., Raven P., 2009b, Hydromorfologiczna ocena wód ptynących, Podręcznik do badań terenowych wedtug metody River Habitat Survey w warunkach Polski, Bogucki Wydawnictwo Naukowe, Poznań-Warrington.

Szoszkiewicz K., Jusik S., Ławniczak A.E., Zgoła T., Szwabińska M., 2010, Zróżnicowanie makrofitów w różnych typach nizinnych rzek referencyjnych w Polsce, Woda-Środowisko-Obszary Wiejskie, 10, 3, s. 297-308.

Walker J., Diamond M., Naura M., 2002, The development of physical habitat objectives, Aquatic Conservation: Marine and Freshwater Ecosystems, 12, 4, s. 381-390.

Wasilewicz M., Oglęcki P., 2006, Porównanie wybranych metod oceny stanu ekologicznego rzek na przykładzie badań środkowej Wkry, Infrastruktura i Ekologia Terenów Wiejskich, 4, 3.

Wiejaczka Ł., 2009, Wptyw zbiornika wodnego „Klimkówka” na abiotyczne elementy środowiska przyrodniczego w dolinie Ropy, Stacja IGiPZ PAN, Szymbark, maszynopis.

[Wpłynęło: luty; poprawiono: maj 2011 r.]

\section{MAŁGORZATA KIJOWSKA, ŁUKASZ WIEJACZKA}

\section{APPLICATION OF THE RHS METHOD IN HYDROMORPHOLOGICAL STUDIES OF A MOUNTAIN RIVER ABOVE AND BELOW A STORAGE RESERVOIR (AS EXEMPLIFIED BY THE ROPA RIVER IN THE BESKID NISKI MTS.)}

The Water Framework Directive (WFD) introduces a duty to monitor and assess the hydromorphological state of rivers in order to determine reference conditions, and planning operations which are elements of catchment management such as flood protection and river renaturalisation. The hydromorphological state of a river depends on the number of natural and anthropogenic elements present along it, as well as their relative proportions. The greater the predominance of natural elements, the better the ecological condition of a river. A dominance of anthropogenic components shows a clear transformation of the river environment by human activity.

Among the many methods used to assess the hydromorphology of rivers, one best suited to this type of hydromorphological research is the River Habitat Survey (RHS), which was developed at the beginning of the 1990s by the British Environment Agency, and is consistent with the requirements of the European Committee for Standard- 
ization CEN (Comiteé Européen de Normalisation) as regards the Water Framework Directive. RHS is also the method used most commonly in Europe, including since the mid 1990s in Poland.

Application of the RHS method allows for the detailed description of hydromorphological conditions along a selected $500 \mathrm{~m}$ representative section of a river. Research is conducted in two phases, with the first entailing a basic morphological characterisation of channel bottom and banks in 10 control profiles (spaced every $50 \mathrm{~m}$ ), as well as an assessment of the structure of aquatic and bank vegetation and land use; while the second includes a synthetic description of the whole section in which account is taken of different morphological forms and transformations not recorded in the previous phase.

Research carried out according to the RHS method allows for the collection of some about 400 parameters characterising the hydromorphological state of the given river. Collected material makes it possible to calculate synthetic indicators (HQA the Habitat Quality Assessment index and HMS - the Habitat Modification Score) as a consequence of many individual basic parameters which allow the hydromorphological state of a river to be presented in numerical form. A river is characterised by the best hydromorphological conditions in case of a high HQA value and a low HMS value.

The functioning of reservoirs has a significant influence on the hydromorphological state of rivers, along sections remaining within range of such anthropogenic objects. Dissepiment of a river by a dam causes dynamic imbalance in the river channel, ensuring that two distinct sections of the river with different hydromorphological conditions are created. The relevance of assessments of the hydromorphological state of rivers with reservoirs along them reflects the need to identify types of change that occur in the riparian environment once a reservoir has started working.

This article presents the preliminary results of hydromorphological inventorying along the River Ropa (Beskid Niski range), after 16 years of operation of the Klimkówka Reservoir. The study was conducted on two selected sections of the river, located above and below the Reservoir. The primary objective of the research, apart from the hydromorphological inventory of the Ropa channel, was an attempt to test the RHS method in the conditions of a mountain river. Most Polish studies that have used the RHS method hitherto have concerned lowland rivers in the central and northern parts of Poland.

The hydromorphological characterisation of the two selected sections of the Ropa, based on fieldwork carried out using the RHS method, revealed both similarities and significant differences between the examined sections isolated by the Klimkówka Reservoir. Incompatibility of hydromorphological features along the examined sections is the result of natural causes, such as the geology and morphology of the area, but is mostly nevertheless associated with human activity, including the functioning of the retention reservoir. However, the impact of Klimkówka does not in fact play the decisive role here, that role being played by regulation of the river with a view to patency being maintained and protection of banks against erosion assured, etc. This is especially the case in the section above the reservoir. Thus, the channel of the Ropa above the reservoir is paradoxically more modified by human activity than the stretch below the dam, along which the anthropogenic impact should in theory be much greater. This observation was confirmed by values for the HMS index - of 18 
for the section above the reservoir, compared with 11 below the dam (both sections generally show little transformation of hydromorphological conditions). HQA index values (50 above and 56 below the reservoir) evidence adequate naturalness of the Ropa's hydromorphological state, though the section below the dam has a relatively greater number and variety of natural morphological elements within the channel and in close proximity to the river.

Overall, the studies conducted on the Ropa show that the RHS method can also be applied in mountain and piedmont areas, albeit after a slight modification of the original form of the system, especially as regards the proper selection of the components that are to be subject to registration. The RHS method also requires the codification and clarification of terms used, which may be incomprehensible to the reader and deviate from terms used in various fields of the environmental sciences and engineering. Also of more major importance is the verification of the interval classes for the indicators, along with their adaptation to reference conditions, whose determination in the case of southern Poland is a very difficult matter that requires many years of research and the collection of quite an extensive database. The specific nature of rivers in mountain and piedmont areas, i.e. with large variations along relatively short sections of river, ensures how important the choice of sections to be made subject to hydromorphological assessment is. This is confirmed by the various hydromorphological conditions recorded in the channel of the River Ropa above and below the Klimkówka Reservoir. 
http://rcin.org.pl 
Tabela 2. Porównanie stanu hydromorfologicznego Ropy powyżej i poniżej zbiornika retencyjnego Klimkówka

A comparison of the hydromorphological state of the Ropa above and below the Klimkówka Reservoir

\begin{tabular}{|c|c|c|c|c|}
\hline $\begin{array}{l}\text { Charakterystyka } \\
\text { Characteristics }\end{array}$ & \multicolumn{2}{|c|}{$\begin{array}{l}\text { Powyżej zbiornika } \\
\text { Above reservoir }\end{array}$} & \multicolumn{2}{|c|}{$\begin{array}{l}\text { Poniżej zbiornika } \\
\text { Below reservoir }\end{array}$} \\
\hline Kształt doliny & \multicolumn{2}{|l|}{ płaskodenna } & \multicolumn{2}{|l|}{ przełomowa } \\
\hline Shape of valley & \multicolumn{2}{|l|}{ flat-bottom valley } & \multicolumn{2}{|l|}{ gorge valley } \\
\hline $\begin{array}{l}\text { Liczba bystrzy, plos i odsypów } \\
\text { meandrowych }\end{array}$ & \multicolumn{2}{|l|}{1 bystrze } & \multicolumn{2}{|c|}{$\begin{array}{l}3 \text { bystrza, } 3 \text { plosa, } 1 \text { odsyp meandrowy nieutrwalony } \\
\text { roślinnością }\end{array}$} \\
\hline $\begin{array}{l}\text { The number of swift current, } \\
\text { river pools and meander bars }\end{array}$ & \multicolumn{2}{|l|}{1 swift current } & \multicolumn{2}{|c|}{3 swift current, 3 river pools, 1 meander bar } \\
\hline Budowle wodne & \multicolumn{2}{|l|}{ most średni i mały } & \multicolumn{2}{|l|}{ most średni, przeprawa duża } \\
\hline Water structures & \multicolumn{2}{|l|}{ small and medium bridge } & \multicolumn{2}{|l|}{ medium bridge, river crossing } \\
\hline \multicolumn{5}{|l|}{ Koryto / Channel } \\
\hline Materiał dna & \multicolumn{2}{|l|}{ kamyki/żwir*, kamienie } & \multicolumn{2}{|c|}{ kamienie*, kamyki/żwir, głazy } \\
\hline Bedrock material & & \multicolumn{2}{|c|}{ coarse pebbles*, pebbles/gravel, stones } \\
\hline Typ przepływu & \multicolumn{2}{|l|}{ wartki*, rwący } & \multicolumn{2}{|c|}{ gładki*, wartki, rwący, chaotyczny } \\
\hline Type of flow & \multicolumn{2}{|l|}{ rapid*, swift } & \multicolumn{2}{|c|}{ smooth $^{*}$, rapid, swift, chaotic } \\
\hline Modyfikacje koryta & \multicolumn{2}{|l|}{ brak*, profilowanie } & \multicolumn{2}{|l|}{ 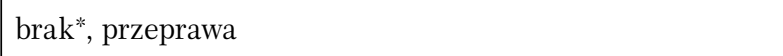 } \\
\hline Channel modifications & \multicolumn{2}{|l|}{ lack*, profiling } & \multicolumn{2}{|l|}{ lack*, crossing the river } \\
\hline $\begin{array}{l}\text { Naturalne elementy } \\
\text { morfologiczne }\end{array}$ & \multicolumn{2}{|l|}{ brak*, odsłonięte głazy } & \multicolumn{2}{|c|}{$\begin{array}{l}\text { brak*, odsłonięte głazy, odsyp śródkorytowy nieutrwalony } \\
\text { roślinnością, odsyp śródkorytowy utrwalony roślinnością }\end{array}$} \\
\hline $\begin{array}{l}\text { Natural morphological } \\
\text { elements }\end{array}$ & lack*, unveiled stones & & $\begin{array}{l}\text { lack*, unveiled stones, middle } \\
\text { middle channel alluvium with }\end{array}$ & $\begin{array}{l}\text { channel non-vegetated bar, } \\
\text { h vegetation }\end{array}$ \\
\hline Typy roślinności w korycie & brak & & wątrobowce/mchy & \\
\hline Vegetation type in channel & lack & & liverworts/bryophyta & \\
\hline $\begin{array}{l}\text { Zadrzewienia i elementy } \\
\text { im towarzyszące }\end{array}$ & $\begin{array}{l}\text { odizolowane, rozproszone, rę } \\
\text { dyncze, rozproszone kępy, pó1 } \\
\text { odkryte korzenie na brzegu, r }\end{array}$ & $\begin{array}{l}\text { talarnie rozmieszczone poje- } \\
\text { tciagłe, zacienienie koryta, } \\
\text { umosz drzewny }\end{array}$ & $\begin{array}{l}\text { odizolowane, rozproszone, roz } \\
\text { zacienienie koryta, zwisające } \\
\text { brzegu, powalone drzewa }\end{array}$ & $\begin{array}{l}\text { zproszone kępy, półciągłe, } \\
\text { konary, odkryte korzenie na }\end{array}$ \\
\hline $\begin{array}{l}\text { Plantings and accompanying } \\
\text { elements }\end{array}$ & $\begin{array}{l}\text { isolated, distributed, regular } \\
\text { semicontinuous, channel shac } \\
\text { bank, woody debris }\end{array}$ & $\begin{array}{l}\text { single, distributed clumps, } \\
\text { ding, exposed roots on the }\end{array}$ & $\begin{array}{l}\text { isolated, distributed, distribut } \\
\text { branches, semicontinuous, chc } \\
\text { on the bank, fallen trees }\end{array}$ & $\begin{array}{l}\text { ted clumps, overhanging } \\
\text { annel shading, exposed roots }\end{array}$ \\
\hline $\begin{array}{l}\text { Czynniki degradujące } \\
\text { środowisko }\end{array}$ & śmieci, droga & & śmieci, tama, droga & \\
\hline $\begin{array}{l}\text { Factors degrading the } \\
\text { environment }\end{array}$ & rubbish, road & & rubbish, dam, road & \\
\hline Brzeg / Bank & lewy / left & prawy / right & lewy / left & prawy / right \\
\hline Materiał brzegu & $\begin{array}{l}\text { ziemia*, kamienie, żwir/pia- } \\
\text { sek, narzut kamienny }\end{array}$ & $\begin{array}{l}\text { ziemia**, narzut kamien- } \\
\text { ny**, żwir/piasek }\end{array}$ & ziemia*, kamienie & $\begin{array}{l}\text { ziemia*, narzut kamienny, } \\
\text { okładziny betonowe }\end{array}$ \\
\hline Bank material & $\begin{array}{l}\text { soil*, coarse pebbles, gravel/ } \\
\text { sand, riprap }\end{array}$ & soil $^{* * *}$, riprap $^{* * *}$ gravel/sand & soil*, coarse pebbles & $\begin{array}{l}\text { soil }{ }^{*} \text {, riprap, concrete cover- } \\
\text { ing }\end{array}$ \\
\hline Modyfikacje brzegu & $\begin{array}{l}\text { brak*, umocnienia, profilo- }^{*} \\
\text { wanie }\end{array}$ & $\begin{array}{l}\text { umocnienia* brak, profilo- } \\
\text { wanie }\end{array}$ & brak $^{*}$ & brak*, umocnienia \\
\hline Bank modifications & $\begin{array}{l}\text { lack }{ }^{*}, \text { bank protection, } \\
\text { profiling }\end{array}$ & $\begin{array}{l}\text { bank protection*, lack, } \\
\text { profiling }\end{array}$ & $l a c k^{*}$ & lack*, bank protection \\
\hline $\begin{array}{l}\text { Naturalne elementy } \\
\text { morfologiczne }\end{array}$ & $\begin{array}{l}\text { brak }^{* *}, \text { odsyp brzegowy } \\
\text { nieutrwalony roślinnością*** } \\
\text { erodujące podcięcie brzegu }\end{array}$ & $\begin{array}{l}\text { brak*, odsyp brzegowy } \\
\text { nieutrwalony roślinnością }\end{array}$ & $\begin{array}{l}\text { brak*, odsyp meandrowy } \\
\text { nieutrwalony roślinnością, } \\
\text { odsyp brzegowy utrwalony } \\
\text { roślinnością }\end{array}$ & $\begin{array}{l}\text { brak*, odsyp brzegowy } \\
\text { nieutrwalony roślinnością, } \\
\text { erodujące podcięcie brzegu }\end{array}$ \\
\hline $\begin{array}{l}\text { Natural morphological } \\
\text { elements }\end{array}$ & $\begin{array}{l}\text { lack }^{* *}, \text { meander non-vege- } \\
\text { tated bar**, bank undercuts }\end{array}$ & $\begin{array}{l}\text { lack*, meander non-vegetat- } \\
\text { ed bar }\end{array}$ & $\begin{array}{l}\text { lack*, meander bar without } \\
\text { vegetation, meander non- } \\
\text { vegetated bar }\end{array}$ & $\begin{array}{l}\text { lack*, meander non-vegetat- } \\
\text { ed bar, bank undercuts }\end{array}$ \\
\hline $\begin{array}{l}\text { Użytkowanie szczytu brze- } \\
\text { gu i struktura roślinności } \\
\text { Bank summit use and } \\
\text { vegetation structure }\end{array}$ & lewy / left & prawy / right & lewy / left & prawy / right \\
\hline $\begin{array}{l}\text { Użytkowanie terenu w pasie } \\
5 \text { m od szczytu }\end{array}$ & $\begin{array}{l}\text { zakrzaczenia*, wysokie zioło- } \\
\text { rośla, intensywnie użytkowa- } \\
\text { ne łąki, grunty orne }\end{array}$ & $\begin{array}{l}\text { zakrzaczenia**, zabudowa } \\
\text { podmiejska**, lasy liściaste/ } \\
\text { mieszane, intensywnie } \\
\text { użytkowane łąki }\end{array}$ & $\begin{array}{l}\text { zabudowa podmiejska*, } \\
\text { zakrzaczenia, wysokie zioło- } \\
\text { rośla, lasy liściaste/mieszane }\end{array}$ & $\begin{array}{l}\text { lasy liściaste/mieszane*, } \\
\text { zabudowa podmiejska }\end{array}$ \\
\hline $\begin{array}{l}\text { Land use in the } 5 \mathrm{~m} \text { belt from } \\
\text { summit }\end{array}$ & $\begin{array}{l}\text { bush*,high herbs intensive } \\
\text { meadows, arable land }\end{array}$ & $\begin{array}{l}\text { bush }^{* *}, \text { suburban building } \\
\text { deciduous forests/ mixed } \\
\text { forests, intensive meadows }\end{array}$ & $\begin{array}{l}\text { suburban building *, bush, } \\
\text { high herbs, deciduous for- } \\
\text { ests/ mixed forests }\end{array}$ & $\begin{array}{l}\text { deciduous forests/ mixed } \\
\text { forests*, suburban building }\end{array}$ \\
\hline Szczyt brzegu & prosta* $^{*}$ jednolita, brak & prosta* & prosta*, jednolita, brak & prosta*, jednolita, brak \\
\hline Bank summit & simple*, homogeneous, lack & simple* & simple*, homogeneous, lack & simple ${ }^{*}$, homogeneous, lack \\
\hline Stok brzegu & prosta*, brak, jednolita & brak ${ }^{*}$, prosta, jednolita & prosta*, jednolita & brak ${ }^{*}$, prosta, jednolita \\
\hline Bank slope & simple*, lack homogeneous & lack*, simple, homogeneous & simple ${ }^{*}$, homogeneous & lack*, simple, homogeneous \\
\hline
\end{tabular}

* dominacja / domination

*** współdominacja / domination of two elements. 